\title{
(2)
}

Current Legal Issues

Hand, 'House of Lords Reform: Many Anniversaries and a False Dichotomy?' [2009] 4 Web JCLI

http://webjcli.ncl.ac.uk/2009/issue4/hand4.html

\section{House of Lords Reform: Many Anniversaries and a False Dichotomy?}

\author{
James Hand \\ BA (Hons), LLM, PgDL, PgDipLP, PgCertLTHE \\ Associate Senior Lecturer \\ School of Law, \\ Portsmouth Business School, \\ University of Portsmouth, \\ Richmond Building, \\ Portland Street, \\ Portsmouth \\ PO1 3DE
}

Email: James.Hand@port.ac.uk

Copyright (C) 2009 James Hand

First published in Web Journal of Current Legal Issues

\section{Summary}

The Government's latest attempts to reform the House of Lords coincide with a number of significant anniversaries of previous attempts. This article notes the Secretary of State for Justice's adoption of the 100th anniversary of the Parliament Act 1911 as a target to get the reform legislation through, examines what can be learnt from those previous attempts and suggests that the debate over election versus appointment may involve a false dichotomy.

\section{Contents}

Introduction

The Introduction of Life Peerages

The 1968 White Paper: Undilute Patronage, Complexity and an Unholy Alliance

The House of Lords Act 1999 and the Weatherill amendment

The Government's Next Steps: Three White Papers, Two Free Votes...

A False Dichotomy? 


\section{Introduction}

11 November 2009 is the $10^{\text {th }}$ anniversary of the House of Lords Act 1999, the Act which, following an amendment tabled by Lord Weatherill, expelled all but 92 of the hereditary peers from the House of Lords. This Act was always going to be 'stage one' of the reforms and the retention of a small number of hereditary peers was, as noted by Lord Irvine LC, designed to act as a guarantor of further reform in stage 2 (1999a, col 207). The 2009-2010 session of Parliament will also see legislation "to complete the process of removing the hereditary principle from the second chamber" and "a draft bill for a smaller and democratically constituted second chamber" (Brown 2009, col 24), thereby breaching the agreement behind the Weatherill amendment which was "negotiated between Privy Councillors on Privy Council terms and binding in honour on all those who have come to give it their assent" (Lord Irvine, 1999a, col 207).

These new proposals are the latest in a long line of White Papers and discussion documents (e.g. White Paper 2008, White Paper 2007, White Paper 2001, DCA 2003) since stage one reform. In the House of Commons debate following the publication of the 2008 White Paper on reform of the House of Lords, the Lord Chancellor and Secretary of State for Justice, Jack Straw MP, agreed that the $100^{\text {th }}$ anniversary of the Parliament Act 1911 would be a good target for getting the reform legislation onto the statute books - but considered that the process would be most unlikely to be complete by then (2008, col. 27). The Parliament Act 1911 was passed following the House of Lords rejection of the Liberal government's budget of 1909 and the subsequent failure of cross-party talks on reform to come to an agreement. Rather than deal with the question of composition then, the government decided simply to limit the delaying power of the House of Lords to two sessions, stating in the preamble that it "intended to substitute for the House of Lords as it at present exists a Second Chamber constituted on a popular instead of hereditary basis, but such substitution cannot be immediately brought into operation". The fact that that two-stage reform remained incomplete was instrumental in the adoption of the Weatherill amendment (Lord Cranborne 1999, cols.221-222), as the remaining 92 hereditary peers would act as an impetus on the Labour party to progress to stage 2.

However, those are just two of the recent or forthcoming significant anniversaries of attempts (both successful and unsuccessful) to reform the upper chamber - and while the Lord Chancellor and Secretary of State for Justice may consider the centenary of the Parliament Act 1911 to be a good target date, an analysis of some of the other anniversaries may prove to be more instructive.

2008 saw the centenary of the Roseberry Report, the $90^{\text {th }}$ anniversary of the Bryce Report, the $50^{\text {th }}$ anniversary of the Life Peerages Act 1958, the $40^{\text {th }}$ anniversary of the 1968 White Paper, and the $30^{\text {th }}$ anniversary of the Home Committee. Coming up is not only the centenary of the Parliament Act 1911, but this year sees the $60^{\text {th }}$ anniversary of its amending Act, the Parliament Act 1949, and the $10^{\text {th }}$ anniversary of the Wakeham Commission itself (the pre-cursor to the current White Paper and its 
two predecessors). There are some common aspects within these attempted reforms, not least the difficulty in attaining consensus and the inclusion of an appointed element.

As with the current White Paper, the report of Viscount Bryce's committee in 1918, as well as those of Lord Home (1978) and of Lord Wakeham's Royal Commission (2000), proposed some form of hybrid house. Bryce favoured a composition whereby approximately 75 per cent would be indirectly elected by MPs in regional groups, with the remainder being a dwindling number of hereditary peers and bishops and an increasing number of other appointees; Home preferred 60 per cent to be elected, either directly or indirectly, thereby enhancing legitimacy while maintaining some continuity, history and breadth of interest and experience; whereas Wakeham proposed a "significant minority" (p.8) of regional elected members (between 12 per cent and 35 per cent depending on which of their three models was used) with the remainder being appointed. Although the Wakeham Report informed "above all" the discussions leading to the current White Paper (Straw 2008, col.21) and although its principles of composition were accepted by the Government in 2000 (Russell \& Cornes 2001, p.99), its recommendations on composition have been inverted, following the decision to take the votes in the House of Commons in March 2007 as indicating that only a wholly elected House or an 80 per cent elected house should merit consideration. All of these reform proposals would have constituted, or constitute, a revolutionary change to the House, and all the historic plans have failed to come to fruition, but all have accepted that appointment brings with it some benefits to the House (see e.g. Wakeham 2000, paras. 11.19 and 11.29 and White Paper 2008, para.6.14). To a large extent, these are the same benefits that the introduction of life peers either brought to the House or enhanced.

\section{The Introduction of Life Peerages}

Life peerages had been a feature of many reform attempts in the late $19^{\text {th }}$ and early $20^{\text {th }}$ centuries (there were second readings of bills by e.g. Lord Russell in 1869, Lord Salisbury in 1888 and Lord Rockley in 1935), following the ruling in the Wensleydale Case (1856) 5 HLC 958; 10 ER 1181 that Sir James Parke, who had been created a baron for life so as to inject legal knowledge into the House, was not in fact entitled to sit in the House of Lords. The solution in that case was to give Sir James Parke, a noted judge who was by then in his mid-70s and who had no male heir, a hereditary barony. Judicial peers went on to be introduced by the Appellate Jurisdiction Act 1876 and they were granted life tenure 11 years later by section 2 of the Appellate Jurisdiction Act 1887. It took some 70 years after that, for life peerages to be granted in general.

The list of the first non-judicial life peers to be members of the House of Lords was announced on $24^{\text {th }}$ July 1958, the Life Peerages Act 1958 having received Royal Assent on $30^{\text {th }}$ April. Over the years this was to progressively allow the House to draw on an even wider range of experience, start to redress the hereditary bias toward the Conservatives, improve the flexibility to appoint people to government and lead to a more representative House. ${ }^{1}$ Among the 14 peers on the first list were the first four

\footnotetext{
${ }^{1}$ There have been well over 1,000 life peerages created in the past 50 years (many more than the total number of hereditary peerages still extant) but life tenure has prevented the House from becoming
} 
women to be members of the House of Lords. 50 years on, while there is a long way to go before the House of Lords could claim to be fully representative of the nation, it has more female members than has the House of Commons (19.7 per cent against 19.4 per cent) - and proportionally considerably more when one looks solely at the life peers (where women make up 24 per cent). (Figures are drawn from data available from the House of Lords Public Information Office and are as at 30 June 2008. The figure for life peers is so much higher than for the whole House as the remaining hereditary peers, Lords (and former Lords) of Appeal in Ordinary, and Bishops are, unsurprisingly, overwhelmingly male). Furthermore, not only is the proportion of black and Asian minority ethnic members, at 4.8 per cent, more than twice that of the Commons but it is also greater than the proportion of black and Asian minority ethnic councillors in local government (and the contrast is heightened when looking at ethnic minority women who comprise 2 per cent of the Lords, less than 1 per cent of councillors and 0.3 per cent of the Commons). ${ }^{2}$

\section{The 1968 White Paper: Undilute Patronage, Complexity and an Unholy Alliance}

While the power of appointment has some clear advantages, there are also some significant, and commonly cited, drawbacks. The increased power of prime ministerial patronage was one of a number of criticisms of the 1968 White Paper. This White Paper proposed a different sort of hybrid house with two tiers of members: those who could vote and those who could only sit and speak. There would be some 230 voting peers whereas those who had previously inherited their title, those aged over 72 and those who did not play an active part in the House would not be eligible to vote but could otherwise take part in activities (but there would be no such right to sit for those who subsequently inherited a title). Other principles included that the government was to be given a small majority over the opposition, but not an overall majority due to the presence of the number of Crossbenchers, and the power of delay was to be reduced to 6 months.

The removal of the hereditary peers (whose presence helped to dissolve the power of patronage), the inequity in there being second-class members, the complexity of determining who was a voting member, the possible tendency to increase the use of the reduced power of delay (in inverse proportion to its strength) and the existence of many other issues, of greater importance to the Labour party and to the electorate, that should be dealt with instead were just some of the criticisms levied at the proposals (Baroness Asquith of Yarnbury 1968, col.696; Lord Gardiner LC 1968, col. 646; Lord Coneford 1968, col. 792; Dorey 2006, pp. 604-607). Although the White Paper was endorsed by the House of Lords, after a three-day debate, by 251 votes to 56, it fared less well in the Commons. The subsequent bill, the Parliament (No. 2) Bill, which had its Commons second reading in January 1969, was withdrawn on $17^{\text {th }}$ April 1969

\footnotetext{
unduly large. As can be seen in the circumstances surrounding the Wensleydale Case, the hereditary principle acted to reduce the number of peerages that were created.

${ }^{2}$ The comparative figures for black and Asian minority ethnic members are 2.3 per cent for the House of Commons (15/645) and under 4 per cent of local councilors ("Today 2.7 per cent of councillors are Asian and 0.5 per cent of councillors are Black", Watson 2007). The figure of less than 1 per cent for black and Asian minority ethnic women councillors, and that there are only 2 minority ethnic women MPs out of 645, is drawn from a written statement by the Minister for Women and Equality (Harman 2008, col. 8WS).
} 
while in committee, following a long delaying action fought by the 'unholy alliance' of Enoch Powell and Michael Foot. Although coming from different sides - with Powell contending that the House had historic legitimacy and Foot, asserting the supremacy of the Commons, taking a unicameralist position (and failing that preferring a less legitimate second chamber as that would not rival the Commons) they, together with others, obstructed the progress of the bill so successfully that by April 1969 only the preamble and the first five clauses had been debated (Dorey 2006, p.608).

\section{The House of Lords Act 1999 and the Weatherill amendment}

The complexity, and to some extent the undilute patronage, of the White Paper and Bill of 40 years ago was avoided with regard to the House of Lords Act 1999 through the expediency of the adoption of both a two-stage approach and the Weatherill amendment. The Blair government proposed that stage one should see the abolition of the hereditary peers' right to sit, with full reform, stage two, occurring after an investigation of the role and powers of the House (i.e. the Royal Commission on Reform of the House of Lords chaired by Lord Wakeham). Concern by the Labour party that Conservative opposition could obstruct the Bill abolishing the hereditary peers' right, and concern by the opposition that stage 2 reform could be as longcoming as that presaged in the preamble to the Parliament Act 1911 (Cranborne 1999, col. 221), led to a consensus-seeking proposal tabled by Lord Weatherill that a block of hereditary peers should remain until stage two reform occurred. Along with the hereditary Royal Office holders - the Earl Marshall and Lord Great Chamberlain and the number of hereditary peers who acted as deputy speakers or held other similar posts, one-tenth of the hereditary peers were to remain, elected among their number (Lord Weatherill 1999, cols. 213-215). The then Lord Chancellor, Lord Irvine, acknowledged that the hereditary peers who remained under the system would have greater authority because of their election by their peers and that their presence would guarantee a second stage of reform given the Labour manifesto commitment to end the hereditary presence (1999a, col 207). The House of Lords Act 1999 received Royal Assent on $11^{\text {th }}$ November 1999 and took effect when the new parliamentary session began six days later.

Now nearly ten years on from the stage one reform, it is clear that stage two has indeed been slow in coming. While there has undoubtedly been a lot of work, with the report of the Royal Commission and now three White Papers, further actual reform appears to remain almost continually on the horizon and no closer. However, the length of time - well over twice that envisaged by Lord Irvine (1999b, col 24) - gives a greater opportunity to look at the 'transitional' house.

As noted above, the House of Lords can now claim to be more representative in its composition, in terms of gender and ethnicity, than the House of Commons (and in terms of ethnicity than the body of local councils). Whereas the old House of Lords had a Conservative bias, there are now similar numbers of Labour, Conservative and Cross-bench peers (215, 202 and 203 respectively as of 30 June 2008). This increase in balance has coincided with an increase in the assertiveness of the House of Lords (government defeats in the years following the passage of the House of Lords Act 1999 have risen on average by around 50 per cent to almost 60 defeats a session (White Paper 2008, para. 2.5)). The process of election has also had an effect on the 
hereditary peers' comparative attendance. Previously decried as backwoodsmen, the average attendance figures for the 'Weatherill' hereditary peers far exceeds that of the life peers. In the parliamentary session 1998/99, the hereditary peers' average attendance was just under two-thirds that of the average life peer whereas in the sessions following the passing of the House of Lords Act 1999 the Weatherill hereditary peers' average is regularly around 130 per cent of that of the average life peer. However, while stage one reform has redressed a number of concerns, the Labour government officially remains committed to introducing stage two reform.

\begin{tabular}{|l|c|c|c|}
\hline & \multicolumn{3}{|c|}{ Average attendance (days) (N.B. length of session varies) } \\
\hline & Hereditary Peers & $\begin{array}{l}\text { 'Weatherill' } \\
\text { Hereditary Peers }\end{array}$ & Life Peers \\
\hline $1998 / 1999$ & 53.5 & --- & 81.9 \\
\hline $2001 / 2002$ & --- & 93.7 & 69.2 \\
\hline $2002 / 2003$ & --- & 115.1 & 87.2 \\
\hline $2003 / 2004$ & --- & 116.5 & 89.6 \\
\hline $2004 / 2005$ & --- & 111.1 & 83.7 \\
\hline $2005 / 2006$ & --- & 98.1 & 74.7 \\
\hline $2006 / 2007$ & --- & 105.1 & 83.2 \\
\hline
\end{tabular}

\section{The Government's Next Steps: Three White Papers, Two Free Votes...}

Their first attempt at stage two reform, the White Paper published in June 2001 in response to the report of the Royal Commission on House of Lords Reform, proposed a 20 per cent elected house with the remainder being appointees ( 20 per cent independent and 60 per cent party appointees). This ran into strong Labour backbench opposition, with a number of calls for a larger elected element, and was dropped in May 2002. Phillipson (2004, p.356) considers that the February 2002 proposals of the Public Administration Select Committee more closely represented MPs' views; it juggled the Royal Commission's proportions so that there would be 60 per cent elected and 20 per cent party political appointees with the remaining 20 per cent being independent appointees (Fifth Report 2002, para 96).

Following the revolt of their own backbench to their proposals, the Labour government then adopted a cross-party approach. This initially led to seven options (from wholly appointed through to wholly elected) being placed before both Houses and the almost farcical situation in February 2003 where the House of Commons voted against all seven. A government Bill introduced in late 2003 to remove the remaining hereditary peers was withdrawn in 2004 following Labour and Conservative fears that it would not so much be the herald of stage two but turn out to be the final reform and as such leave too much patronage with government even with an independent appointments commission (Dorey 2006, p.615). The re-run of the 2003 free vote in March 2007, following the February 2007 White Paper 'House of Lords: Reform', saw the House of Commons vote in favour of the wholly elected option (by 337 to 224) and 80 per cent elected options (by a much smaller margin of 305 to 267). The House of Lords, however, voted only for a 100 per cent appointed 
House, and there is some argument that the level of the support in the Commons for a wholly elected House was the result of political maneuvering and does not reflect the true feeling of the Commons (e.g. Sir Patrick Cormack 2008, cols.28-29: "the vote for 100 per cent. was caused by a tactical switch by a number of Members, led by the hon. Member for Tyne Bridge (Mr. Clelland), who is nodding vigorously"). Nevertheless, the government decided that the July 2008 White Paper should only consider the options which had received support in the House of Commons.

The July 2008 White Paper thus only considered the options of an 80 per cent and a wholly elected House - and does not decide on either but instead leaves it open for further consultation. This is just one of a number of points that the White Paper left open and that is one of the reasons it was not well received, coming in for criticism in both Houses (HL Deb 2008; HC Deb 2008), by the media (e.g. Wintour 2008, July 19; Riddell 2008, July 15; Norton 2008, July 15) and from a former speaker of the House of Commons (- "Boothroyd puts boot into Straw", Birmingham Evening Mail, July 16, 2008). Although it is a government White Paper it is again the product of cross-party discussions and there are areas where there has been no agreement (e.g. whether to use first-past-the-post or another electoral system and, if an 80 per cent elected house is chosen, the presence of Bishops and the status of the appointments commission). However, it is clear that the powers of the House of Lords should not be reduced (White Paper 2008, chapter 5) despite there earlier having been proposals to limit scrutiny of bills to just 60 days and, as with the 1968 White Paper, cut the power to delay to 6 months (Dorey, 2006, p.617).

Among the more concrete reforms is the proposal that elected members of the reformed House should serve 12-15 year terms and not be available for re-election (an idea designed to enhance independence which has been a feature of many other reform proposals, e.g. Wakeham and Bryce). The government also proposes that members should be salaried and, while leaving the fine detail open, proposes on principle that members' salary should be less than that of MPs but more than that of members of devolved legislatures (which would mean at today's prices that a member elected for 12 years would receive some $£ 600,000$ ). The method of election, the transitional arrangements (with three possibilities considered with final end dates ranging from 2020 to 2040) and, less intractably, the presence of both Bishops (which is opposed by the Liberal Democrats but which otherwise is either accepted or does not attract forceful opposition, according to the study by Harlow, Cranmer and Doe 2008) and retired Justices of the Supreme Court ${ }^{3}$ all remain open. Although the White Paper does not decide on whether the reformed House should be wholly or 80 per cent elected, it does note the difficulty of including an independent element within a wholly elected chamber (para 6.12).

Despite the preamble to the Parliament Act 1911, an appointed element has been a key feature of many reform proposals from Bryce 90 years ago to Home 30 years ago and Wakeham 10 years ago, as well those over the last 10 years. As Phillipson (2004,

\footnotetext{
${ }^{3}$ While the White Paper considers that retired Justices of the Supreme Court, like many other notable figures such as retired Cabinet Secretaries, Chiefs of the Defence Staff, Archbishops, etc., could be considered for appointment by the Appointments Commission 'in the normal way' (para 6.58) as part of the 20 per cent, the Lord Chancellor and Secretary of State for Justice in the debate appeared to agree with a point that allied them with the Lords Spiritual (Straw 2008, col. 26) in response to the Shadow Secretary of State (Herbert 2008, col. 25).
} 
pp.352-354) notes, hybridity seemed to be favoured by the government until just before the February 2003 indicative votes on composition when it was described by Lord Irvine LC, among others, as a "nonsense" and a "parliamentary disaster". Nevertheless, the debate has been over how big the elected and appointed elements should be (from Wakeham's 12 per cent-35 per cent to the Public Administration Select Committee's 80 per cent via the government's original 20 per cent). However, the debate over election versus appointment, and as to the proportions of a hybrid House, may well be a false dichotomy.

\section{A False Dichotomy?}

Following on from last year's $50^{\text {th }}$ anniversary of the Life Peerage Act and this year's $10^{\text {th }}$ anniversary of the House of Lords Act, arguably both very valuable and successful reforms, a 'Weatherill 2' system - extending the principle of the Weatherill hereditaries to Life Peers (but with the numbers of party peers changing according to, for example, either general or local election results) - could provide a combination of the benefits of election and appointment while mitigating some of the problems with both.

It would also satisfy all the principles which, in framing the February 2007 White Paper, the government laid down as underpinning reform of the House of Lords:

"Primacy of the House of Commons; Complementarity of the House of Lords;

A More Legitimate House of Lords;

No Overall Majority for Any Party;

Non Party-Political Element;

A More Representative House of Lords;

Continuity of Membership" (White Paper 2007, p.25)

as well as the addition in the July 2008 that "the second chamber should take account of the prevailing political view amongst the electorate, but also provide opportunities for independent and minority views to be represented" (White Paper 2008, p.4).

Such a system would bear a resemblance to that proposed by the Roseberry report (the $80^{\text {th }}$ anniversary of which was last year) ${ }^{4}$ but with a democratic difference. Roseberry proposed that the House of Lords should consist of a number of representative peers elected by peers (according to type of peerage) along with those peers who had held high office, elected bishops, Lords of Appeal in Ordinary and a small number of life peers. The idea foundered due to a fatal defect, from the Liberal's point of view, as it entrenched a Tory majority and removed their ability to threaten to flood the House of Lords with new members (Holland 1912, pp.52-53). There is no such majority today. Rather than having peers elected according to type (e.g. so many Dukes, so many Marquesses, etc.), as with Roseberry, or the Weatherill system of each party's hereditary peers electing, in 1999, 10 per cent of their number to represent them (with

\footnotetext{
${ }^{4}$ It also bears some resemblance to a proposal put forward by Lord Pearson during the passage of the House of Lords Act 1999 but which was opposed as it was introduced as an alternative to the already accepted Weatherill amendment rather than as a proposal for stage 2. In Lord Pearson's proposal, the numbers of elected Cross-bench, Conservative, Labour and Liberal Democrat peers would be fixed by statute at 240, 200, 200 and 60 respectively (Lord Pearson 1999, cols 43-59).
} 
subsequent by-elections), the number of sitting peers for the political parties would vary according to recent election results. The number of cross-bench peers could be fixed close to the current level and thus provide a far greater independent element than the 2008 White Paper, with its maximum of 20 per cent appointees, could allow. The election of peers from within their own number to fill the parties' allocations would avoid the house growing to such a gargantuan size which would, as Hazell and Seyd (1998, p.383) illustrate, be inherent in a system whereby life peerages are created to ensure proportionality between the parties. There could, however, also be a provision to allow for a small number of peers to be appointed directly to the House, for example to take up ministerial positions (as with Lady Chalker in the previous Conservative government and Lord Malloch-Brown, among others, in the current Labour government), who would then face election at the next opportunity.

It would thus take account of the prevailing political view among the electorate, whilst preserving an element of flexibility in appointment to government and maintaining a strong independent element that would contribute to ensuring that there was no overall majority for any party. The indirect election would, as stated in the July 2008 White Paper, "offer some degree of democratic legitimacy" (para.4.35). While indirect election was eschewed by the White Paper, the stated objections were the difficulties in deciding which institutions should be represented in any electoral college, the short-term nature of the secondary mandate and the similarity to appointment (paras $4.35-4.41$ ). This does would not apply to a 'Weatherill 2' system as the direct electorate would be the party and cross-bench life peers and the doublelock of being made a peer and then facing election would dilute the similarity to simple appointment. Furthermore, while there would be some variation in the numbers for each party, there would be substantial continuity of membership, and, indeed, the mechanism for election could operate on the widely mooted three-term system if wanted. While indirect election does not confer as much legitimacy as direct election, it does meet the requirements of enhanced legitimacy and complementarity, does not challenge the primacy of the House of Commons in the way that a directly elected House using proportional representation might, does not risk increasing voter fatigue, and should save much of the additional $£ 43$ million pounds that the direct elections are estimated to cost (White Paper 2008, para. 9.3).

Such a system would build on the reforms of the Life Peerage Act 1958 and House of Lords Act 1999 and be in keeping with the evolutionary changes of the House. Although there are strong and opposing views held on all sides, unlike the revolutionary changes proposed within the 2008 White Paper - and indeed earlier failed attempts such as the 1968 White Paper and the Bryce Report (1918) - the changes would be simpler, and are a development of what has already been tried and tested and proved successful, and thus there are fewer areas for contention. The system combines much of the benefits of election and appointment, allows for a greater independent element and does not create a two-tier house which hybridity risks. Moreover, it does away with the need for long and complex transitional arrangements, potentially running until the middle of this century. Instead, following the precedent of the House of Lords Act 1999, it could be a short and relatively simple Act and be in operation within weeks, or even days, of being enacted. The 100th anniversary of the 1911 Act could thus be well within sight. 


\section{Bibliography}

Baroness Asquith of Yarnbury (1968), HL Deb vol 297, col 696, 19 November 1968.

Brown, G (2009) HC Deb vol 495, col 24, 29 Jun 2009.

Bryce Report (1918) Conference on the Reform of the Second Chamber (London: HMSO) Cd. 9038.

Lord Coneford (1968) HL Deb vol 297, col 792, 19 November 1968.

Cormack, P (2008) HC Deb vol 479, cols 28-29, 14 July 2008.

Lord Cranborne (1999), HL Deb vol 599, cols 221-222, 30 March 1999.

Department for Constitutional Affairs (2003) Constitutional Reform: Next steps for the House of Lords (London: DCA).

Dorey, P (2006) '1949, 1969, 1999: The Labour Party and House of Lords Reform’ 59 Parliamentary Affairs 599.

Fifth Report (2002) Fifth Report HC Public Administration Select Committee Session 2001-02, HC 494-I.

Lord Gardiner LC (1968) HL Deb vol 297, col 646, 19 November 1968.

Harlow, A, Cranmer, F \& Doe, N (2008) 'Bishops in the House of Lords: a critical analysis' Public Law 490.

Harman, H (2008) HC Deb vol 476, col 8WS, 19 May 2008.

Hazell, R \& Seyd, B (1998) 'Reforming the Lords: the numbers' Public Law 378.

HC Deb (2008) HC Deb vol 479, cols 24 - 36, 14 July 2008.

Herbert, N (2008) HC Deb vol 479, col 25, 14 July 2008.

HL Deb (2008) HL Deb vol 703, cols 990 - 1002, 14 July 2008.

Holland, F (ed) (1912) The Constitutional History of England since the Accession of George III by the Right Hon. Sir Thomas Erskine May, vol. III (London: Longmans, Green \& Co).

Lord Home (1978) Report of the Review Committee on the Second Chamber (London: Conservative Political Centre).

Lord Irvine (1999a) HL Deb vol 599, col. 207, 30 March 1999.

Lord Irvine (1999b) HL Deb vol 602, col 24, 15 June 1999. 
Norton, P (2008) 'Call that a White Paper?', Lords of The Blog, July 15, 2008 Available at $<$ http://lordsoftheblog.wordpress.com/2008/07/15/call-that-a-whitepaper/> accessed July 3, 2009.

Lord Pearson (1999) HL Deb vol 601, cols 43-59, 17 May 1999.

Phillipson, G (2004) ""The greatest quango of them all", "a rival Chamber" or "a hybrid nonsense"? Solving the second chamber paradox' Public Law 352.

Riddell, P (2008) 'Missed the Lords reform? There'll be another along soon', The Times, July 15, 2008.

Russell, M \& Cornes, R (2001) 'The Royal Commission on Reform of the House of Lords: A House for the Future?’ 64 Modern Law Review 82.

Straw, J (2008) HC Deb vol 479, col 27, 14 July 2008.

Lord Wakeham (2000) Royal Commission on Reform of the House of Lords: A House for the Future (London: TSO) Cm. 4534.

Watson, S (2007) "BME councillors represent 4 per cent of local government" Operation Black Vote, February 14, 2007 Available at $<$ http://www.obv.org.uk/index.php?option=com_content\&task=view\&id=623\&Itemid $=128>$, accessed July 3, 2009 .

Lord Weatherill (1999) HL Deb vol 599, cols 213-215, 30 March 1999.

White Paper (1968) House of Lords Reform (London: HMSO) Cmnd. 3799.

White Paper (2001) The House of Lords: Completing the Reform (London: TSO) Cm 5291.

White Paper (2007) The House of Lords: Reform (London: TSO) Cm 7027.

White Paper (2008) An Elected Second Chamber - Further reform of the House of Lords (London: TSO) Cm 7438.

Wintour, P (2008) 'Move to block Labour support for elected House of Lords', The Guardian, July 19, 2008.

-- "Boothroyd puts boot into Straw", Birmingham Evening Mail, July 16, 2008. 